\title{
SEARCHING WIDELY OR DEEPLY? THE IMPACT OF OPEN INNOVATION ON INNOVATION PERFORMANCE AMONG INDONESIAN MANUFACTURING FIRMS
}

\author{
Arif Hartono \\ Faculty of Economics, Universitas Islam Indonesia, Indonesia \\ (arif.hartono@uii.ac.id) \\ Ratih Kusumawardhani \\ Faculty of Economics, Universitas Sarjanawiyata Tamansiswa, Indonesia \\ (ratihkusuma@ustjogja.ac.id)
}

\begin{abstract}
Since the term Open Innovation (OI) was coined by Henry Chesbrough in 2003, OI studies have been frequently conducted. Surprisingly, OI insights, in the context of Indonesian firms, are scarce. Furthermore, there are no existing OI studies that use data derived from innovation surveys. Hence, this study attempts to close the gap in the literature, by providing insights into Indonesian firms' openness toward external knowledge, and its impact on innovation performance. The main aim of this study is to investigate the impact of OI practices on Indonesian manufacturing firms' propensity to innovate (i.e. their product, process, organization, and marketing) and innovation performance. Product and process innovations are grouped under the term technological innovation, while organization and marketing innovations are classified as non-technological innovation. Data used in this study were derived from the Indonesia Innovation Survey (IIS) 2011 that covered the period from 2009-2010. Following Laursen and Salter's (2006) study, OI indicators consist of external search breadth (i.e. the number of external sources or search channels that firms rely upon in their innovative activities) and depth (the extent to which firms draw deeply from the different external sources or search channels) in innovation process. Undertaking logistic and tobit regressions, this study shows that in general, both breadth and depth significantly and positively affect technological and nontechnological innovation, as well as innovation performance. However, the over-search on external knowledge, measured by breadth squared and depth squared, negatively and significantly influence innovation and innovation performance. This indicates that too much external knowledge, sourced during the innovation process will diminish the return of innovation. This study also finds an indication of a complementary relationship existing between internal R\&D and external knowledge; meaning that the implementation of one knowledge-sourcing strategy (either sourcing from internal R\&D or external knowledge) increases the marginal returns from another. Lastly, important implications related to theoretical and innovation strategies are proposed.
\end{abstract}

Keywords: open innovation, manufacturing firms, Indonesia

JEL Classification: 0310, 0320 


\section{INTRODUCTION}

The concept of Open Innovation (OI) has gained a great deal of attention since Henry Chesbrough published the first book on OI in 2003. However, most studies tend to focus on OI as a firm level analysis in technologically advanced countries (Podmetina, Fiegenbaum, Teplov, \& Albats, 2014). Business management studies suggest that efforts to search for new information, ideas and knowledge go beyond firms' boundaries, in order to explore and exploit the available knowledge and capabilities of other firms. Such a suggestion is in line with the OI paradigm that assumes "firms can and should use external ideas as well as internal ideas, and internal and external paths to market, as the firms look to advance their technology" (Chesbrough, 2003, p. xxiv). OI is defined as "the use of purposive inflows and outflows of knowledge to accelerate internal innovation and expand the market for the external use of innovation" (Chesbrough, 2006, p. 1). Therefore, firms that use an OI model can and should use internal and external ideas, and internal and external paths to their markets, in order to explore and realise innovative opportunities, and the model can be compared with the closed model in which the firms generate, develop, and market their own ideas, usually by conducting internal R\&D activities (De Jong, Vanhaverbeke, Kalvet, \& Chesbrough, 2008). In addition, "the open innovation paradigm does not imply that internal $R \& D$ is obsolete. Internal R\&D can still be a source of better performance, as it was in the old days. It also increases the absorptive capacity to better benefit from external sources" (De Jong et al., 2008, p. 5).

Different perspectives related to OI have been studied in the context of developing countries, such as a case study on the link between OI and the open business model in Brazil (Aranha, Prado Garcia, \& Corrêa, 2015), the impact of the external environment on OI in Russia (Savitskaya \& Podmetina, 2013), the impact of OI on financial performance in India (Kafouros \& Forsans, 2012), diverse topics related to $\mathrm{OI}$ in China $(\mathrm{Fu}, \mathrm{Li}$, Xiong, \& Chesbrough, 2014; Fu \& Xiong, 2012; Savitskaya, Salmi, \& Torkkeli, 2010; Wang, Vanhaverbeke, Roijakkers, \& Chen, 2011; Xiaobao, Wei, \& Yuzhen, 2013), and factors that motivate and prevent OI's adoption in Turkey (Sağ, Sezen, \& Güzel, 2016). However, OI insights in the context of Indonesian firms are scarce, especially OI studies that exploit innovation data that is comparable with the Community Innovation Survey (CIS), which has been used extensively in developed countries in Europe.

Although innovation studies have been conducted, previous studies in Indonesia's context tend to be scattered, and none of them pay attention to OI, which is a relatively new topic in the innovation management literature. The previous studies can be classified into several topics. First, the influence of innovation on competitiveness and business performance in a specific industry sector, for instance, the marine and fisheries industry (Yusuf \& Trondsen, 2013) and the digital creative industry (Yahya, 2013). Second, the innovation issues of small and medium firms, such as collaboration and innovation's adoption in small-scale industry clusters (Sandee \& Rietveld, 2001); innovation and information flows in small-scale cottage industries in rural areas (Kristiansen, 2002); sources of knowledge in small-scale furniture industries (Indarti \& Van Geenhuizen, 2005); and the innovation and cooperation activities of SMEs in food processing industry clusters (Najib \& Kiminami, 2011). Third, the technological capabilities and commercialization, for example the technological capabilities comparison between Indonesian and Malaysian 
automotive firms (Rasiah, 2009) and technology's commercialization activities (Dhewanto \& Umam, 2009). Fourth, innovation strategy and the national innovation system, for example, a sequential model of the innovation strategy of oil and gas companies (Ciptono, 2006) and innovative national innovation systems (Lakitan, 2013). Lastly, studies into the sources of knowledge and its impact on innovation performance; for instance, the role of academia as external sources of innovation in the automotive industry (Aminullah and Adnan, 2012); how knowledge spillovers from multinational enterprises influence local $R \& D$ activities (Todo \& Miyamoto, 2006); and the breadth and depth sources of knowledge and its impact on Indonesian restaurants and cafes' innovation capabilities (Utami, Indarti, Sitalaksmi, \& Makodian, 2017). The last example may be related to OI practices, however, it focused on a specific industry i.e. the service industry as operated in restaurants and cafes.

Using the data from the Indonesia Innovation Survey (IIS) 2011, this study aims to provide new empirical evidence on the impact of OI practices on Indonesian manufacturing firms' propensity to innovate, and their innovation performance. The IIS 2011 focused on Indonesian manufacturing firms' innovation activities during 2009 - 2010. Therefore, a principal research question driving this study is: "To what extent OI practices influence Indonesian manufacturing firms' propensity to innovate and thus their innovation performance?" Following the work of Laursen and Salter (2006) which argues that firms' abilities to exploit external knowledge are crucial for innovation performance, we explore the link between OI and the different types of innovation (i.e. product, process, organizational and marketing) and the innovation performance among Indonesian manufacturing firms.

To the best of our knowledge, there is no existing study that used data derived from the IIS to investigate the OI practices performed by Indonesian firms. It is expected this study will be the pioneer that empirically investigates the impact of OI practices on innovation and innovation performance. Hence, this study sheds light on OI practices, in the context of Indonesian firms, and contributes to the theoretical and practical knowledge that can enrich the OI literature in the developing countries' context.

The remaining sections of this study are organised as follows: In the next section (Section two) the literature review and hypotheses development are presented. In this section, the importance of OI for firms in developing countries, as well as the impact of OI on innovation performance is discussed. Section three explains the data and the methods used in this study. Furthermore, Section three describes the data, the variables and the methods used for testing the proposed hypotheses. Section four reports the results and explains to what extent the proposed hypotheses have been confirmed. The final section contains the discussion and conclusions.

\section{LITERATURE REVIEW}

\section{Firms in Developing Countries and OI Practices}

It is often argued that many firms in the developing economies rely on a "reinventing the wheel" strategy and do not rely heavily on their R\&D efforts (Basant \& Fikkert, 1996); accordingly the imitation and acquisition of technology seem to be more important than performing R\&D and innovation activities (Bell \& Pavitt, 1993). Fu et al. (2014) argues that most 
firms in developing countries are still in a transition stage, trying to catch-up and to build their innovation capabilities; therefore, innovation can be viewed as a process of learning and assimilating knowledge, in order to catch-up with technological frontiers (Fransman \& King, 1984). Even the most technologically advanced firms in developing economies are involved in external knowledge sourcing activities (Freeman, 1989). Hence, the cultivation of an indigenous innovation capability can be based on sourcing activities from external resources and knowledge (Kim, 1997b, 1997a).

A common innovation strategy performed by firms in developing countries is to complement their own knowledge generation with external knowledge sourcing activities (e.g. acquiring advanced technology from developed countries). The following are examples of such strategies: Deolalikar and Evenson (1989) found a complementary effect between internal $R \& D$ and technology transferred from abroad among Indian firms; in Brazilian industries, a robust complementary relationship is found between technology firms' efforts and technology firms' buying (Braga \& Willmore, 1991). In a recent study, Kafouros and Forsans (2012) examined the interaction between internal $R \& D$ and the sourcing of external scientific knowledge activities, as well as the impact of those activities on Indian firms' financial performance. They reveal that internal $R \& D$ has a stronger impact on performance for firms that are more open to external scientific knowledge and technologies. Such a finding is in line with the OI paradigm, and it implies that firms should carefully determine their balance between internal and external knowledge; firms should not rely heavily on everything inside them, and substituting internal research with external knowledge is likely to decrease the firms' performance (Kafouros and Forsans, 2012). A positive and significant effect of R\&D's intensity on openness is also found in a study based on Chinese innovation survey data conducted by Fu et al. (2014).

Although the growing concern is for using indigenous $R \& D$ efforts in the innovation process in emerging countries, however "opening up the innovation process is likely to be a natural choice for latecomers in emerging economies, to mitigate $\mathrm{R} \& \mathrm{D}$ pressure, overcome various constrains, diversity risks and share uncertainties" (Fu et al., 2014, p. 177) and as an effort to catch-up with advanced economies. The OI perspective emphasizes the important value of external knowledge and internal R\&D activities as efforts to absorb the available external knowledge outside the firms' boundaries.

\section{Indonesia's Innovation Environment and OI Practices}

Like many other developing countries, Indonesian firms face a diversity of challenges related to innovation activities. An important and common barrier that hinders innovation activities in the context of developing or poor countries is the ability to finance innovation activities (Ayyagari, Demirgüç-Kunt, \& Maksimovic, 2011). A study that explores the nature of the innovation barriers faced by Indonesian manufacturing firms also places the financial and risk barriers as the most important constraints (Hartono \& Kusumawardhani, 2019). In terms of public and business investment in $\mathrm{R} \& \mathrm{D}$, Indonesia spends very little, compared to developed countries or even compared to countries in the ASEAN region. Indonesia's investment in its Gross Expenditure on R\&D (GERD) has always been very small, it has never exceeded $0.2 \%$, and most of it has occurred in the public sector (Hill \& Tandon, 2010). Of five ASEAN countries (i.e. Indonesia, Malaysia, 
Thailand, Vietnam, and the Philippines), only Indonesia had no experience in increasing scientific knowledge's acquirement through R\&D, and since 2000 it has constantly deteriorated and occupied the bottom position (Aminullah, 2007). As the investment in GERD is relatively low, and dominated by public funding with little contribution from the private sector, there is a limited ability to mobilize the resources required for innovation (Baark, 2016). Aminullah (2012) argues that the constantly low investment in national $R \& D$ is due to the following three reasons: (1) Private $R \& D$ investment is very low; (2) a large proportion of the industrial sector is dominated by low and medium technology industries that do not require $R \& D$, and (3) government attention to support the development of Science, Technology and Innovation (STI) is constantly declining.

Most Indonesian firms do not invest in R\&D, they tend to rely on technologies developed elsewhere (Wie, 2005). Hence, Indonesian government institutes perform $81 \%$ of GERD (OECD, 2013). Unlike many OECD countries, where the business sector is the dominant source of $R \& D$ funding, government funding of $R \& D$ is the most common funding source in Indonesia.

In terms of viewing science and technology's performance, patent applications can be used as a way to measure R\&D's output. However, it is important to note that not all inventions are patented. Indonesia is behind the top innovating countries, e.g. Korea, as well as its more immediate neighbor Malaysia, in terms of patents granted (Hill and Tandon, 2010). Referring to US Patent and Trademark Office (USPTO) data, the number of patents from Indonesia in the 1990s was relatively comparable with some ASEAN countries such as Malaysia, Thailand, and the Philippines. However, since 2000 , the Indonesian position has fallen behind Malaysia and Thailand (Aminullah, 2007).

In terms of linkages and knowledge flows, firms and industries are part of larger interlinked systems involving market and non-market knowledge. In Indonesia, knowledge used for innovation, especially in the manufacturing sectors, is generated from learning through informal experiences and not through formal scientific activities or intense R\&D (Aminullah, 2012; Aminullah, Dian, Irene, \& Laksani, 2014). Modes of learning can be: (1) Learning by doing through working on the production floor; (2) learning by using through the use of machinery, equipment and production systems; (3) learning by interacting through interactions with users, suppliers, parent companies in the design and modification of products and the production process; and (4) learning by modeling, through the success of past experiences as a role model for the future (Aminullah, 2012; Aminullah et al., 2014).

Based on the aforementioned explanation, it may be concluded that instead of having a reliance on their internal capabilities and resources, Indonesian firms would be better off by opening up their innovation activities, allowing them to deal with diverse constraints, as this is in line with the argument by Fu et al. (2014) that the implementation of OI is a natural choice for firms in developing countries. However, insights into Indonesian manufacturing firms' openness toward external knowledge and its impact on their innovation propensity and innovation performance are few and far between.

\section{OI Practices and Innovation Performance}

Searching for new ideas that have commercial potential is the main part of the innovation process (Laursen \& Salter, 2006) and "the way firms' organize their search ideas, knowledge, and information, has become a central part of the 
modern innovation process" (Laursen, Paananen, \& Salter, 2007, p. 2), and it is argued that the implementation of different search strategies can yield different innovative performances (Laursen $\&$ Salter, 2004).

In general, previous OI studies in both the developed and developing countries reveal a significant and positive relationship between openness and innovation performance, with variations in the relationship due to the differentiation of the external search breadth versus depth and the use of domestic versus overseas sources of knowledge. Following Laursen and Salter's (2006) study, openness toward external knowledge use for innovation refers to the breadth of the external search (BREADTH) and the depth of the external search (DEPTH). BREADTH is defined as "the number of external sources or search channels that firms rely upon in their innovative activities", while DEPTH is defined as "the extent to which firms draw deeply from the different external sources or search channels" (Laursen and Salter, 2006, p. 134).

In the context of developed economies, a majority of the OI studies that exploit data from innovation surveys (e.g. community innovation surveys) found that OI practices positively affect innovation and the innovation performance. Using the UK innovation survey, a pioneer of innovation survey-based open innovation studies conducted by Laursen and Salter (2006), it was found that searching external knowledge both widely and deeply positively impacted on innovation performance. Other open innovation studies using various innovation surveys (Ahn, Mortara, \& Minshall, 2014; Battisti, Gallego, Rubalcaba, \& Windrum, 2015; Ebersberger, Bloch, Herstad, \& Van De Velde, 2012; Laursen et al., 2007; Salge, Bohne, Farchi, \& Piening, 2012) reveal a significant and positive relationship between openness and innovation performance.

Recent OI studies in developing economies, for example in China, found that many firms that face various constraints and risks for innovations related to their market/institutions, capability/ skills, and finance, tend to search with a greater external breadth and depth ( $\mathrm{Fu}$ et al., 2014). Another example is a study of Indian firms that shows "inbound open innovation is crucial in helping firms to catch-up and move toward the technological frontier" (Kafouros \& Forsans, 2012, p. 362). However, insights from OI practices in developing countries are rather scarce, and limited to qualitative studies because data collection is rather complicated (Podmetina et al., 2014), with some notable exceptions (Fu et al., 2014; Kafouros \& Forsans, 2012). Hence, a hypothesis related to the impact of OI practices on innovation propensity and innovation performance can be proposed.

\section{H1: External search BREADTH and DEPTH positively influence innovation and innovation performance.}

Although a positive association between OI and innovation performance has been found, some studies reveal that 'over searching' external knowledge tends to diminish the innovation performance. For example, Laursen and Salter (2006) found that the relationship between openness and innovative performance was curvilinear (taking an inverted U-shape). Using panel data from Finnish firms, Laursen et al., (2007) revealed that the relationship between a firm's openness to external knowledge and its profitability is curvilinear, showing that there are decreasing returns from external knowledge's searching activity. A curvilinear relationship between OI and innovation performance was also found in the context of small firms. For example, evidence of such a relationship can be 
found in Irish small firms (Vahter, Love, \& Roper, 2014). To measure such a relationship, a majority of the previous studies tested the impact of BREATH squared and DEPTH squared on innovation performance (Laursen et al., 2007; Laursen \& Salter, 2006). Hence, a hypothesis related to a curvilinear relationship between OI practices and innovation performance can be proposed.

\section{H2: A curvilinear relationship exists between OI practices and innovation performance.}

\section{METHOD, DATA AND ANALYSIS}

\section{Data}

Data used in this study are derived from the Indonesia Innovation Survey (IIS) 2011 that covers 2009-2010. In terms of firm size, the IIS 2011 surveyed only medium (20-99 employees) and large (more than 99 employees) Indonesian manufacturing firms. The surveyed firms are classified based on the International Standard Industrial Classification (ISIC) Rev. 3.1. Multistage random sampling was used to collect data from 1,500 firms and a total of 1,375 questionnaires were successfully collected. Of the returned questionnaires, 1,179 were usable. Face-to-face interviews with $R \& D$ or production managers were conducted to collect the data. The IIS 2011 used the Oslo Manual (OECD/ Eurostat, 2005) as the guideline for collecting and interpreting the innovation data, and adjustments were made to facilitate innovation activities in Indonesia that may differ from those in developed economies.

Table 1 shows the distribution of the sample and population, based on the types of industry. In the case of the manufacturing sectors, the following are among the top five industries: Food and beverage (26.21\%), textiles (10.69\%), clothing $(8.99 \%)$, furniture $(8.99 \%)$ and nonmetallic mineral products $(8.31 \%)$. The lowest proportion was from coke, refined petroleum products, nuclear and fuel $(0.08 \%)$ and office accounting and computing machinery (0.08\%) industries. Table 2 displays the proportion of survey responses based on the firms' technology intensity and size. The surveyed firms are dominated by low technology industries (73.45\%), while high-technology industries only accounted for $0.93 \%$. The same patterns were also found for both medium and large firms.

\section{Variables and Measures}

Dependent variables consist of the innovation propensity, such as for product innovation (PRODINOV), product innovation to the Indonesia market (PRODINOV2MARKET), product innovation new to the firms (PRODINOV2FIRMS), process innovation (PROCINOV), organizational innovation (ORGINOV) and marketing innovation (MKTGINOV) as well as innovation performance (INNOVPERFORM), while the independent variables are BREADTH and DEPTH. Following previous studies (Mothe \& Thi, 2010; Pippel, 2014; Schmidt \& Rammer, 2006), the four types of innovation are classified as either technological or non-technological innovations. Product and process are traditional innovations that normally are classified as technological innovations, while organizational and marketing are grouped under nontechnological innovations (Mothe \& Thi, 2010; Pippel, 2014; Schmidt \& Rammer, 2006). The technological innovation approach tends to focus on the manufacturing sector and neglects the non-technological approach, which covers a broader range of innovations such as are found in the organizational or marketing approach that are normally implemented in the service sector. However, technological and non-technological innovations are linked to each other and often occur simultaneously (Pippel, 2014). 
The four types of innovation used in this study are in line with the Oslo Manual $3^{\text {rd }}$ Edition: Guidelines for collecting and interpreting innovation data (OECD \& EUROSTAT, 2005) and below are the definitions of each type of innovation based on the Oslo Manual.

"A product innovation is the introduction of a good or service that is new or significantly improved with respect to its characteristics or intended uses. This includes significant improvements in technical specifications, components and materials, incorporated software, user-friendliness or other functional characteristics " (OECD \& EUROSTAT, 2005, p. 48).

"A process innovation is the implementation of a new or significantly improved production or delivery method. This includes significant changes in techniques, equipment and/or software" (OECD \& EUROSTAT, 2005, p. 49).

"A marketing innovation is the implementation of a new marketing method involving significant changes in product design or packaging, product placement, product promotion or pricing" (OECD \& EUROSTAT, 2005, p. 49).

"An organizational innovation is the implementation of a new organizational method in the firm's business practices, workplace organization or external relations" (OECD \& EUROSTAT, 2005, p. 51).

Knowledge use as the input of innovation consists of internal knowledge generation (i.e. internal R\&D) and external sources of knowledge, as presented in Table 3. To measure all the hypotheses, measurement of the external search breadth (BREADTH) and external search depth (DEPTH) follows Laursen and Salter's (2006) study. BREADTH is constructed based on 9 external sources of knowledge used for innovation, present in the IIS dataset, such as: (1) Suppliers of equipment, materials, components or software (SUPPLIERS); (2) clients or customers (CUSTOMERS); (3) competitors or other enterprises (COMPETITORS); (4) consultants, commercial laboratories or private $R \& D$ institutes (CONSULTANTS); (5) universities or other higher education institutions (UNIVERSITIES); (6) government or public research institutes (GOV_RD); (7) professionals and industry associations (ASSOCIATIONS); conferences, trade fairs, exhibitions (EVENTS); and (9) scientific journals and trade/technical publications (SCIENCE_PUB) (see Table 3).

The BREADTH is defined as the total number of sources used and ranges from 0 when no external information is used, to 9 when all the sources of external information are used. In relation to breadth, Laursen and Salter (2006, p. 140) argue that "firms that use higher numbers of sources are more open, with respect to their search breadth, than firms that are not". Hence, the higher the number for breadth, the more open a firm is. Firstly, each of the 9 sources is coded as a binary variable, 0 being no use and 1 being the use of the given knowledge source. Then, the 9 sources are simply added up so that each firm gets a 0 when no external knowledge sources are used, while the firm gets the value of 9 when all the external knowledge sources are used. A high degree of internal consistency resulted from the BREADTH construct (Cronbach's alpha coefficient $=0.93$ ).

In the case of the DEPTH measurement, firstly, each of the 9 sources are coded with 1 when the firm uses the source to a high degree and 0 in the case of the source either not being used, or there being low or medium use of the given source. Then, the 9 sources are added up so that each firm gets the value of 9 when all the 
knowledge sources are used to a high degree, while each firm gets 0 when no knowledge sources are used to a high degree. A reasonably good internal consistency resulted from this construct (Cronbach's alpha coefficient $=0.65)$.

Table 1. Distribution of sample and population firms by industry (\%)

\begin{tabular}{llcc}
\hline ISIC Rev 3.1 & \multicolumn{1}{c}{ Manufacture Sectors ${ }^{1}$} & $\begin{array}{c}\text { Sample } \\
(1,179 \text { firms })\end{array}$ & $\begin{array}{c}\text { Population }^{2} \\
(23,345 \text { firms })\end{array}$ \\
\hline Division 15 & Food \& beverages & 26.21 & 23.90 \\
Division 16 & Tobacco products & 5.00 & 4.19 \\
Division 17 & Textiles & 10.69 & 11.07 \\
Division 18 & Wearing apparel; dressing and dyeing of fur & 8.99 & 8.43 \\
Division 19 & Tanning and dressing of leather; manufacture of luggage, & 2.97 & 2.84 \\
& handbags, saddlery, harness \& footwear & & \\
Division 20 & Wood and of products of wood and cork, except furniture; & 5.00 & 5.30 \\
& manufacture of articles of straw and plaiting materials & & \\
Division 21 & Paper and paper products & 1.78 & 2.16 \\
Division 22 & Printing and publishing & 3.39 & 1.98 \\
Division 23 & Coke, refined petroleum products, \& nuclear fuel & 0.08 & 0.32 \\
Division 24 & Chemicals \& chemical products & 3.50 & 4.64 \\
Division 25 & Rubber \& plastics products & 5.34 & 7.11 \\
Division 26 & Other non-metallic mineral products & 8.31 & 6.92 \\
Division 27 & Basic metals & 0.51 & 1.10 \\
Division 28 & Fabricated metal products, except machinery and equipment & 3.14 & 3.85 \\
Division 29 & Machinery \& equipment n.e.c. & 1.27 & 1.72 \\
Division 30 & Office, accounting \& computing machinery & 0.08 & 0.04 \\
Division 31 & Electrical machinery \& apparatus n.e.c. & 0.93 & 1.05 \\
Division 32 & Radio, TV \& communication equipment \& apparatus & 0.68 & 0.94 \\
Division 33 & Medical, precision \& optical instruments, watches and clocks & 0.17 & 0.29 \\
Division 34 & Motor vehicles, trailers \& semi-trailers & 1.19 & 1.19 \\
Division 35 & Other transport equipment & 1.27 & 1.40 \\
Division 36 & Furniture; manufacturing n.e.c. & 8.99 & 9.39 \\
Division 37 & Recycling & 0.45 & 0.17 \\
\hline
\end{tabular}

Source: Badan Pusat Statistik (2011)

Table 2. Survey responses by technology intensity and size (\% and quantity)

\begin{tabular}{lccc}
\hline \multicolumn{1}{c}{ Technology intensity } & Medium & Large & Total \\
\hline LOW-TECH (ISIC 15-22, 36-37) & $75.33(681)$ & $67.27(185)$ & $73.45(866)$ \\
MED2LOW-TECH (ISIC 23, 25-28) & $17.48(158)$ & $17.09(47)$ & $17.39(205)$ \\
MED2HIGH-TECH (ISIC 24, 29, 31, 34 \& 35) & $6.64(60)$ & $13.45(37)$ & $8.23(97)$ \\
HIGH-TECH (ISIC 30, 32, 33) & $0.55(5)$ & $2.18(6)$ & $0.93(11)$ \\
\hline Total & $100(904)$ & $100(275)$ & $100(1,179)$ \\
\hline
\end{tabular}

Source: UN Statistics Division (2002) 
Table 3. Variables of the study

\begin{tabular}{|c|c|}
\hline Main Variables & $\begin{array}{l}\text { Description } \\
(0=\text { not used, 1=low, } 2=\text { medium, 4=high) }\end{array}$ \\
\hline \multicolumn{2}{|l|}{ Innovation performance } \\
\hline INNOVPERFORM $(\%)$ & Sales proportion of product innovation new to the market \\
\hline \multicolumn{2}{|l|}{ Types of innovation } \\
\hline PRODINOV $(0 / 1)$ & Product innovation $(0=$ no, $1=$ yes $)$ \\
\hline PRODINOV2MKT (0/1) & Product innovation new to the Indonesia market $(0=$ no, $1=y e s)$ \\
\hline PRODINOV2FIRM (0/1) & Product innovation new to the firms $(0=$ no, $1=$ yes $)$ \\
\hline PROCINOV $(0 / 1)$ & Process innovation $(0=$ no, $1=$ yes $)$ \\
\hline ORGINOV $(0 / 1)$ & Organisational innovation $(0=$ no, $1=$ yes $)$ \\
\hline MKTGINOV $(0 / 1)$ & Marketing innovation $(0=$ no, $1=$ yes $)$ \\
\hline \multicolumn{2}{|l|}{ Sources of knowledge } \\
\hline INTERNAL-RD $(0 / 1)$ & Internal (in-house) research and development $(R \& D)(0=$ no, $1=y e s)$ \\
\hline SUPPLIERS (0/4) & Suppliers of equipment, materials, components or software. \\
\hline CUSTOMERS $(0 / 4)$ & Clients or customers. \\
\hline COMPETITORS $(0 / 4)$ & Competitors/other enterprises in the firm sector. \\
\hline CONSULTANTS $(0 / 4)$ & Consultants, commercial laboratories or private R\&D institutes. \\
\hline UNIVERSITIES (0/4) & Universities/other higher education institutions. \\
\hline PUB_RESEARCH (0/4) & The government/public research institutes. \\
\hline EVENTS (0/4) & Conferences, trade fairs, and exhibitions. \\
\hline PUBLICATIONS (0/4) & Scientific journals and trade/technical publications. \\
\hline ASSOCIATIONS (0/4) & Professional and industry associations. \\
\hline
\end{tabular}

Source: Indonesia Innovation Survey (2011)

\section{Methods}

A logistic regression is used to handle the predictions of, and modeling responses to, the dependent variables, the firms' innovation propensities (i.e. product, process, organizational, and marketing), including product innovations new to the market and firms. Firms that perform any of the four types of innovation are coded 1; otherwise, they are coded 0 . A tobit regression is used to test the impact of $\mathrm{OI}$ on innovation performance, because the dependent variable (i.e. innovation performance) is indicated by the proportion of sales of innovative products new to the market, which is (double) censored with a range between 0 and 100 . Although the complementary relationship between internal knowledge (i.e. internal $R \& D$ ) and the various sources of external knowledge is not the main focus of this study, such a relationship is tested in order to provide information on which specific external knowledge source is complementary with the internal R\&D. Following Roper, Du, \& Love (2008), a probit regression is employed in this study to test whether the relationship between internal R\&D and external knowledge is complementary or a substitution.

\section{RESULT AND DISCUSSION}

\section{Descriptive}

Table 4 presents the descriptive statistics output. Following the $3^{\text {rd }}$ Oslo Manual, the IIS 2011 defines innovation as "the implementation of a new or significantly improved product (goods or services), or process, a new marketing method, or a new organizational method in business 
Table 4. Descriptive statistics

\begin{tabular}{|c|c|c|c|c|c|}
\hline & OBS & MEAN & SD & MIN & MAX \\
\hline \multicolumn{6}{|l|}{ Innovation } \\
\hline INNOVPERFORM & 1,179 & 8.43 & 16.99 & 0 & 100 \\
\hline PRODINOV & 1,179 & 0.377 & 0.485 & 0 & 1 \\
\hline PRODINOV2MKT & 1,179 & 0.288 & 0.453 & 0 & 1 \\
\hline PRODINOV2FIRMS & 1,179 & 0.358 & 0.480 & 0 & 1 \\
\hline PROCINOV & 1,179 & 0.322 & 0.468 & 0 & 1 \\
\hline ORGINOV & 1,179 & 0.310 & 0.463 & 0 & 1 \\
\hline MKTGINOV & 1,179 & 0.428 & 0.495 & 0 & 1 \\
\hline \multicolumn{6}{|l|}{ Sources of knowledge } \\
\hline INTERNAL_RD & 1,179 & 0.292 & 0.455 & 0 & 1 \\
\hline SUPPLIERS & 1,196 & 0.188 & 0.391 & 0 & 4 \\
\hline CUSTOMERS & 1,188 & 0.344 & 0.475 & 0 & 4 \\
\hline COMPETITORS & 1,179 & 0.225 & 0.418 & 0 & 4 \\
\hline CONSULTANTS & 1,179 & 0.041 & 0.198 & 0 & 4 \\
\hline UNIVERSITIES & 1,179 & 0.031 & 0.174 & 0 & 4 \\
\hline PUB_RESEARCH & 1,179 & 0.041 & 0.198 & 0 & 4 \\
\hline ASSOCIATIONS & 1,179 & 0.065 & 0.247 & 0 & 4 \\
\hline EVENTS & 1,188 & 0.109 & 0.312 & 0 & 4 \\
\hline SCIENCE_PUB & 1,188 & 0.067 & 0.251 & 0 & 4 \\
\hline BREADTH & 1,196 & 4.21 & 3.49 & 0 & 9 \\
\hline DEPTH & 1,179 & 1.12 & 1.45 & 0 & 8 \\
\hline \multicolumn{6}{|l|}{ Firm Resources } \\
\hline FIRM_SIZE & 1,179 & 174.61 & $1,318.08$ & 20 & 32,977 \\
\hline FIRM_AGE & 1,179 & 21.077 & 12.704 & 0 & 84 \\
\hline NON_EXPORTERS & 1,179 & 0.809 & 0.393 & 0 & 1 \\
\hline EXPORTERS & 1,179 & 0.036 & 0.185 & 0 & 1 \\
\hline LOW_TECH & 1,179 & 0.735 & 0.442 & 0 & 1 \\
\hline MED2LOW_TECH & 1,179 & 0.174 & 0.379 & 0 & 1 \\
\hline MED2HIGH_TECH & 1,179 & 0.082 & 0.275 & 0 & 1 \\
\hline HIGH_TECH & 1,179 & 0.010 & 0.096 & 0 & 1 \\
\hline EDU_UNDERHS & 1,179 & 56.247 & 36.423 & 0 & 100 \\
\hline EDU_HIGHSCHOOL & 1,179 & 36.430 & 31.492 & 0 & 100 \\
\hline EDU_DIPLOMA & 1,179 & 3.246 & 6.779 & 0 & 55 \\
\hline EDU_UNDERGRAD & 1,179 & 4.077 & 8.623 & 0 & 90 \\
\hline
\end{tabular}

Source: Indonesia Innovation Survey Data (2011), analyzed

practices, workplace organization or external relations" (OECD \& EUROSTAT, 2005, p. 46). Based on this definition, which covers a broad range of possible innovations, the IIS 2011 then defines an innovative firm as any firm that performs any product, process, organizational or marketing innovation from 2009 to 2010. According to Table 1, the highest proportion is marketing innovation (42.8\%), while the lowest is organizational innovation (31\%). The mean of 
product innovations that are new to the market is lower than the same innovations that are new to the firm, and account for $28.8 \%$ versus $35.8 \%$ respectively. The mean of innovation success, as the proportion of launched products new to the market, accounted for $8.43 \%$. The fact that marketing innovations outnumbered the other types of innovation is typical in developing countries, which tend to focus on the market rather than on the technology (Wamae, 2009).

In terms of the sources of knowledge, on average customers form the highest proportion knowledge source used for innovation by the firms (i.e. $34.4 \%$ ). In contrast, less than $5 \%$ of the firms' source knowledge from scientific institutions, for example from universities, government R\&D institutions, and scientific publications. This may indicate that Indonesian manufacturing firms tend to use external knowledge from non-scientific sources of knowledge. Approximately $29 \%$ of the firms' report generating their own knowledge from internal R\&D. In terms of BREADTH, the firms have between 4 to 5 sources of external knowledge, while DEPTH, the firms used 1 to 2 sources of external knowledge intensively.

The mean of firm size, as indicated by the number of employees, is nearly 175 people. Of the surveyed firms, mature firms (more than 20 years) dominate the IIS 2011 data. The proportion of non-exporters is very high (around $81 \%$ ), compared to exporters (nearly 4\%), respectively. This means that most of the surveyed firms have local markets. In terms of their technology intensity, more than $50 \%$ of the firms are low-technology firms. Labor education levels are very low. More than $50 \%$ of the employees have no high school degree, which indicates the low level of education of the firms' human resources. In contrast, less than $5 \%$ of employees hold undergraduate degrees.

\section{Empirical results}

Table 5 displays the logistic regression outputs. It clearly shows that in general the BREADTH and DEPTH variables positively and significantly affect different types of innovation and innovation performance. This finding supports the majority of previous OI studies and hence Hypothesis 1 is supported. However, when the BREADTH squared and DEPTH squared variables are included (see Table 6); both variables negatively and significantly influence innovation outputs and innovation performance. This indicates that over-searching diminishes the return of innovation, and this finding also confirms many previous OI studies or, in other words, a curvilinear relationship exists between OI practices and innovation performance. Hence, Hypotheses 2 is also supported.

Turning to the existence of the complementary relationship, Appendix 2 shows a positive and significant relationship between internal R\&D and various external knowledge sources, such as customers, competitors, consultants, universities and industry associations. This may indicate that complementary relationships exist between internal R\&D and the five external sources of knowledge. In relation to firms' resources and characteristics, surprisingly, there are no positive and significant impacts on either innovation propensity or innovation performance. 


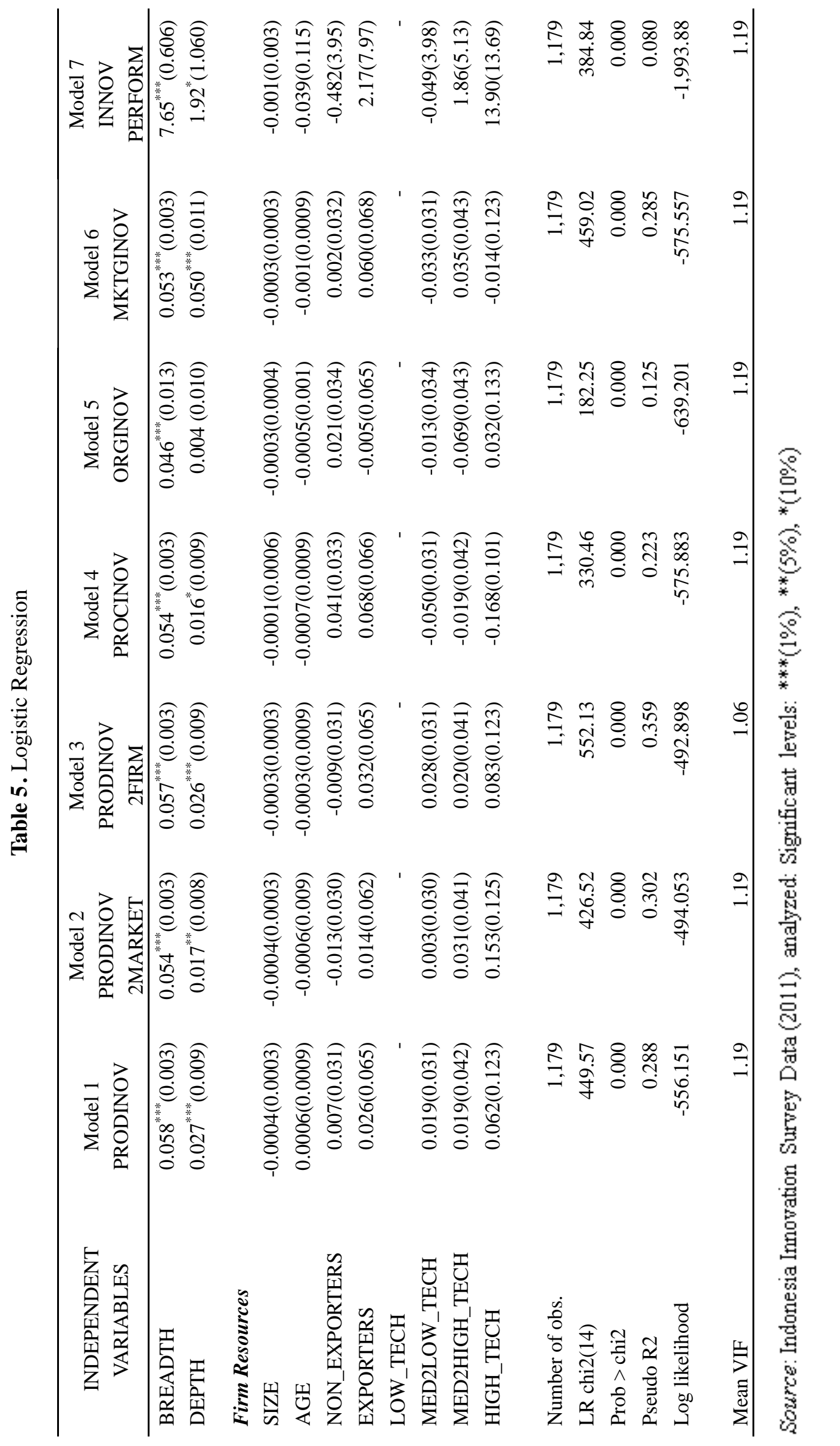




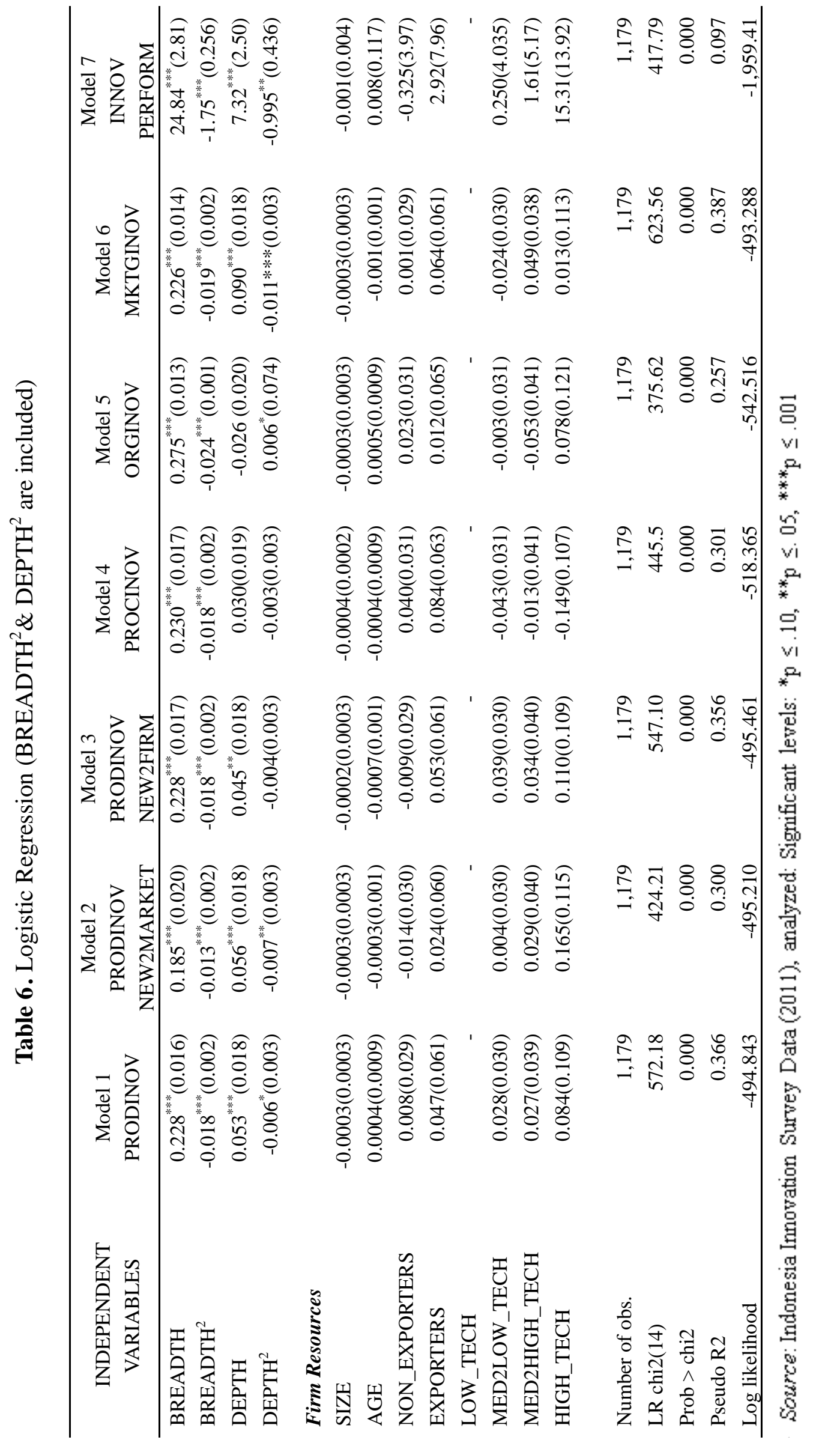




\section{CONCLUSION}

This study aims to investigate the impact of OI practices performed by Indonesian manufacturing firms, represented by their external search breadth and depth, on four types of innovation and innovation performance, using innovation data derived from IIS 2011. To the best our knowledge, in the context of Indonesia, this study is the first empirical study that investigates OI practices using innovation data derived from IIS. Key findings from this study are as follows: First, empirical evidence shows that OI practices are performed by Indonesian manufacturing firms, and such practices have positive impacts on the innovation propensity and innovation performance. These findings support and confirm the majority of previous OI studies in both the developed and developing economies. Second, this study also found that over-searching for external knowledge leads to a negative impact on innovation performance. Hence, there are tipping points in the efforts to search for external knowledge widely and deeply. However, this study does not provide further insight on this issue. An additional finding from this study is related to an indication of the complementary relationship between internal knowledge's generation (i.e. internal or in-house R\&D) and external knowledge searches. It turns out that Indonesian manufacturing firms tend to complement their internal R\&D activities with external knowledge from the market (e.g. customers and suppliers) and open sources (e.g. industry associations and events) in the innovation process.

In summary, this study provides the following theoretical implications: First, this study is the first empirical study that provides an insight into Indonesian manufacturing firms' openness toward external knowledge and its impact on their innovation propensity and innovation performance. The findings of this study contribute to the enrichment of the innovation studies literature, in the context of developing countries (i.e. Indonesia), as previous studies tended to focus on case studies, while previous OI studies using large-scale innovation data do not exist. Hence, it may be concluded that the Indonesian firms, like many other firms in developed economies, also employ OI practices in their innovation processes. Second, this study examines the impact of OI practices on both technological and non-technological innovation, while a majority of the OI studies tends to focus on technological innovation (i.e. product and process innovation) only. Hence, this suggests that OI practices are also beneficial for broader innovations or non-technological innovations i.e. organizational and marketing innovations.

Important implications for managers may be drawn from this study: First, the fact that the firms' openness to external knowledge significantly and positively affects their innovation and innovation performance, it is recommended that innovative firms scan and blend a wide range of external knowledge, rather than relying on their internal R\&D. Innovation managers should search and exploit knowledge for innovation beyond their firms' borders. It is also important to bear in innovation managers' minds that they need to move beyond "research and develop" to "connect and develop" (see Huston \& Sakkab, 2006 for further discussion) to drive their OI strategy. Second, to facilitate an effective external knowledge search, firms should consider an online platform that enables them to reach vast numbers of external knowledge providers who are beyond traditional firms' borders.

\section{LIMITATION AND SUGGESTION}

Lastly, the limitations of the study need to be acknowledged to drive future OI studies, 
especially in Indonesia's context. First, although this study provides interesting insights, these are limited to the manufacturing sector. Hence, future OI studies in the context of Indonesia should address this issue by involving wider sectors, such as the service sector. Second, the nature of this study is cross-sectional, i.e. it only used innovation data from a single innovation wave of the survey, hence, it is impossible to track any changes in the OI practices performed by Indonesian firms. To address this issue, a future study that exploits a longitudinal series of innovation surveys would be interesting. Third, this study only provides an OI framework based on data derived from IIS. Any insights related to factors that motivate or hinder Indonesia firms to perform OI practices are missing. Hence, a future study to address this issue in the context of Indonesian firms would be useful.

\section{ACKNOWLEDGEMENT}

We acknowledge financial support from Indonesia Endowment Fund for Education (LPDP).

\section{REFERENCES}

Ahn, J., Mortara, L., \& Minshall, T. (2014). Longitudinal effects of open R\&D strategy on firm performance: Comparative study of the UK and Korea. 2014 R\&D Management Association Conference, 1-10.

Aminullah, E. (2007). Long term forecasting of technology and economic growth in Indonesia. Asian Journal of Technology Innovation, 15(1), 1-20. https://doi.org/ 10.1080/19761597.2007.9668625.

Aminullah, E. (2012). Coping with low R\&D investment in Indonesia: Policy insights from a system dynamics model. Journal of $S \& T$ Policy and $R \& D$ Management, 10(1), $1-10$.

Aminullah, E., Dian, P., Irene, M. N., \& Laksani, C. S. (2014). How capital goods firms upgrade innovation capacity: A case study. Journal of $S \& T$ Policy and $R \& D$ Management, 12(2), 85-98.

Aranha, E. A., Prado Garcia, N. A., \& Corrêa, G. (2015). Open innovation and business model: A Brazilian company's case study. Journal of Technology Management \& Innovation, 10(4), 91-98. https://doi.org/ 10.4067/S0718-27242015000400010.

Ayyagari, M., Demirgüç-Kunt, A., \& Maksimovic, V. (2011). Firm innovation in emerging markets: The role of finance, governance, and competition. Journal of Financial and Quantitative Analysis, 46(6), 1545-1580. https://doi.org/10.1017/ S0022109011000378.

Baark, E. (2016). Innovation system reform in Indonesia and Vietnam: A new role for universities? Journal of STI Policy and Management, 1(1), 1-15. Retrieved from http://dx.doi.org/10.14203/stipm.v1i1 .

Basant, R., \& Fikkert, B. (1996). The effects of $\mathrm{R} \& \mathrm{D}$, foreign technology purchase, and domestic and international spillovers on productivity in Indian firms. The Review of Economics and Statistics, 78(2), 187-199.

Battisti, G., Gallego, J., Rubalcaba, L., \& Windrum, P. (2015). Open innovation in services: Knowledge sources, intellectual property rights and internationalization. Economics of Innovation and New Technology, 24(3), 223-247. https://doi.org/ 10.1080/10438599.2014.924745.

Bell, M., \& Pavitt, K. (1993). Technological accumulation and industrial growth: Contrasts between developed and developing countries. Industrial and Corporate Change, 2(2), 157-211.

Badan Pusat Statistik. (2011). Statistik industri manufaktur Indonesia. Retrieved from https://www.bps.go.id/publication/2013/05/ 06/ec83eb56cf3bf400eba98f54/statistikindustri-manufaktur-indinesia-2011produksi.html

Braga, H., \& Willmore, L. (1991). Technological imports and technological effort: An 
analysis of their determinants in Brazilian firms. The Journal of Industrial Economics, 39(4), 421-432.

Chesbrough, H. W. (2003). Open Innovation: The New Imperative for Creating and Profiting from Technology. Boston, Massachusetts: Harvard Business School Press.

Chesbrough, H. W. (2006). Open Innovation: A new paradigm for understanding industrial innovation. In H. W. Chesbrough, W. Vanhaverbeke, \& J. West (Ed.), Open innovation: Researching a new paradigm. Oxford, UK: Oxford University Press.

Ciptono, W. S. (2006). A sequential model of innovation strategy-company nonfinancial performance links. International Journal of Purchasiing and Supply Management, 8(2), 137-178.

De Jong, J. P. J., Vanhaverbeke, W., Kalvet, T., \& Chesbrough, H. (2008). Policies for open innovation: Theory, framework and cases. Visionera.net.

Deolalikar, A. B., \& Evenson, R. E. (1989). Technology production and technology purchase in Indian industry: An econometric analysis. The Review of Economics and Statistics, 71(4), 687-692.

Dhewanto, W., \& Umam, K. K. (2009). Technology commercialisation in a developing country: Current condition and its challenges. The Asian Journal of Technology Management, 2(1), 1-13.

Ebersberger, B., Bloch, C., Herstad, S. J., \& Van De Velde, E. (2012). Open innovation practices and their effect on innovation performance. International Journal of Innovation and Technology Management, 09(06), 1250040. https://doi.org/10.1142/ S021987701250040X.

Fransman, M., \& King, K. (1984). Technological capability in the third world. London, UK: The Macmillan Press Ltd.

Freeman, C. (1989). The economics of industrial innovation. London, UK: Francis Pinter.

Fu, X., Li, J., Xiong, H., \& Chesbrough, H. W.
(2014). Open innovation as a response to constraints and risks: Evidence from China. Asian Economic Papers, 13(3), 30-58. https://doi.org/10.1162/ASEP.

$\mathrm{Fu}, \mathrm{X}$., \& Xiong, H. (2012). Open innovation in China: Policies and practices. Oxford, UK.

Hartono, A., \& Kusumawardhani, R. (2019). Innovation barriers and their impact on innovation: Evidence from Indonesian manufacturing firms. Global Business Review, 20(5).

Hill, H., \& Tandon, P. (2010). Innovation and technological capability in Indonesia, (June 2010).

Huston, L., \& Sakkab, N. (2006). Connect and develop. Inside Procter \& Gamble's new model for innovation. Harvard Business Review, 84(3), 58-67. https://doi.org/ 10.1111/j.1943-278X.2010.00006.x.

Indarti, N., \& Van Geenhuizen, M. (2005). Knowledge as a critical resource in innovation among small furniture companies in Indonesia. Gadjah Mada International Journal of Business, 7(3), 371-390. Retrieved from http://search.ebscohost.com/login.aspx?dire $\mathrm{ct}=$ true $\& \mathrm{db}=\mathrm{bth} \& \mathrm{AN}=20025911 \&$ site $=$ edslive.

Kafouros, M. I., \& Forsans, N. (2012). The role of open innovation in emerging economies: Do companies profit from the scientific knowledge of others? Journal of World Business, 47(3), 362-370. https://doi.org/ 10.1016/j.jwb.2011.05.004.

Kim, L. (1997a). Imitation to Innovation: The dynamics of Korea's technological learning. Boston, Massachusetts: Harvard Business School Press.

Kim, L. (1997b). The Dynamics of Samsung's technological learning in semiconductors. California Management Review, 39(3), 86100. https://doi.org/10.2307/41165900.

Kristiansen, S. (2002). Competition and knowledge in Japanese rural businesses. Journal of Tropical Geography, 23(1), 5270. 
Lakitan, B. (2013). Connecting all the dots: Identifying the " actor level" challenges in establishing an effective innovation system in Indonesia. Technology in Society, 35(1), 41-54. https://doi.org/10.1016/ j.techsoc.2013.03.002.

Laursen, K., Paananen, M., \& Salter, A. (2007). Appropriability, proximity, routines and innovation profiting From openness: exploring the relationship between. DRUID Summer Conference.

Laursen, K., \& Salter, A. (2004). Searching high and low: What types of firms use universities as a source of innovation? Research Policy, 33(8), 1201-1215. https://doi.org/10.1016/j.respol.2004.07.004

Laursen, K., \& Salter, A. (2006). Open for innovation: The role of openness in explaining innovation performance among U.K. manufacturing firms. Strategic Management Journal, 27(2), 131-150. https://doi.org/10.1002/smj.507.

Mothe, C., \& Thi, T. U. N. (2010). The link between non-technological innovation and technological innovation. European Journal of Innovation Management, 13(3), 313-332. https://doi.org/10.1108/1460106101106014 8.

Najib, M., \& Kiminami, A. (2011). Innovation, cooperation and business performance. Some evidence from Indonesia's small food processing cluster. Journal of Agribusiness in Developing and Emerging Economies, 1(1), 75-96.

OECD. (2013). Innovation in Southeast Asia. Innovation in Southeast Asia. https://doi.org/10.1787/9789264128712-en

OECD \& EUROSTAT. (2005). Oslo Manual: Guidelines for collecting and interpreting innovation data $\left(3^{\text {rd }}\right.$ ed). Paris, France.

PAPPIPTEK, LIPI. (2011). Indonesia innovation survey data. Unpublishes raw data.

Pippel, G. (2014). R\&D cooperation for nontechnological innovations. Economics of Innovation and New Technology, 23(7), 611-630. https://doi.org/10.1080/
10438599.2013.871167.

Podmetina, D., Fiegenbaum, I., Teplov, R., \& Albats, E. (2014). Towards open innovation measurement systems - A literature review. The XXV ISPIM Conference-Innovation for Sustainable Economy \& Society, Dublin, Ireland.

Rasiah, R. (2009). Technological capabilities of automotive firms in Indonesia and Malaysia. Asian Economic Papers, 8(1), 151-169. https://doi.org/10.1162/asep.2009.8.1.151.

Roper, S., Du, J., \& Love, J. H. (2008). Modelling the innovation value chain. Research Policy, 37(6-7), 961-977. https://doi.org/10.1016/j.respol.2008.04.005

Sağ, S., Sezen, B., \& Güzel, M. (2016). Factors that motivate or prevent the adoption of open innovation by SMEs in developing countries and policy suggestions. Procedia Social and Behavioral Sciences, 235, 756763).

https://doi.org/10.1016/j.sbspro.2016.11.077

Salge, T. O., Bohne, T. M., Farchi, T., \& Piening, E. P. (2012). Harnessing the value of open innovation: the moderating role of innovation management. International Journal of Innovation Management, 16(03), 1-26. https://doi.org/10.1142/ S1363919612400051.

Sandee, H., \& Rietveld, P. (2001). Upgrading traditional technologies in small-scale industry clusters: Collaboration and innovation adoption in Indonesia. The Journal of Development Studies, 37(4), 150-172.

Savitskaya, I., \& Podmetina, D. (2013). Environmental influences on open innovation: Evidence from Russia. International Journal of Business Excellence, 6(3), 310-330. https://doi.org/ 10.1504/IJBEX.2013.053612.

Savitskaya, I., Salmi, P., \& Torkkeli, M. (2010). Barriers to open innovation: Case China. Journal of Technology Management \& Innovation, 5(4), 10-21. https://doi.org/ 10.4067/S0718-27242010000400002. 
Schmidt, T., \& Rammer, C. (2006). The determinants and effects of technological and non- technological innovations Evidence from the German CIS IV. Mannheim: ZEW. Retrieved from http:// www.oecd.org/science/innovationinsciencet echnologyandindustry/37450197.pdf.

Todo, Y., \& Miyamoto, K. (2006). Knowledge spillovers from foreign direct investment and the role of local R\&D activities: evidence from Indonesia. Economic Development and Cultural Change, 55(1), 173-200. https://doi.org/10.1086/505729.

UN Statistics Division. (2002). International standard industrial classification of all economic activities (ISIC), revision 3.1. retrieved from https://unstats.un.org/unsd/publications/catal ogue? selectID=318

Utami, T. L. W., Indarti, N., Sitalaksmi, S., \& Makodian, N. (2017). The Effect of knowledge sources on innovation capabilities among restaurants and café businesses in Indonesia. Journal of Indonesian Economy and Business, 32(1), 33-50.

Vahter, P., Love, J. H., \& Roper, S. (2014). Openness and innovation performance: Are small firms different? Industry and Innovation, 21(7-8), 553-573. https:// doi.org/10.1080/13662716.2015.1012825.

Wamae, W. (2009). Enhancing the role of knowledge and innovation for development. International Journal of Technology Management and Sustainable Development, 8(3), 199-220. https://doi.org/10.1386/ ijtm8.3.199/1.

Wang, Y., Vanhaverbeke, W., Roijakkers, N., \& Chen, J. (2011). How Chinese firms employ open innovation to accelerate the development of their technological capability. SSRN Electronic Journal. https://doi.org/10.2139/ssrn.1925149.

Wie, T. K. (2005). The major channels of international technology transfer to Indonesia: An assessment. Journal of the Asia Pacific Economy, 10(2), 214-236. https://doi.org/10.1080/1354786050007149 3.

Xiaobao, P., Wei, S., \& Yuzhen, D. (2013). Framework of open innovation in SMEs in an emerging economy: Firm characteristics, network openness, and network information. International Journal of Technology Management, 62(2/3/4), 223. https://doi.org/ 10.1504/IJTM.2013.055142.

Yahya, A. (2013). The Effect of unique resource, innovation management and partnership on business performance at digital creative industry in Indonesia. International Journal of Innovation in Business, 2(5), 444-464.

Yusuf, M., \& Trondsen, T. (2013). Improving Indonesia's competitiveness: Innovation, value chains and cluster-bases for realising the huge potential of marine and fisheries. International Journal of Organizational Innovation, 6(1), 128-136. Retrieved from http://0search.ebscohost.com.millenium.ites $\mathrm{m} . \mathrm{mx} / \operatorname{login}$. aspx ?direct=true $\& \mathrm{db}=\mathrm{bth} \& \mathrm{AN}$ $=90515800 \&$ site $=$ ehost-live $\&$ scope $=$ site.

Notice: The Journal of Indonesian Economy and Business and its Board of Editors are not responsible for any errors or flaws found in this article. The authors take full responsibility for their work. 


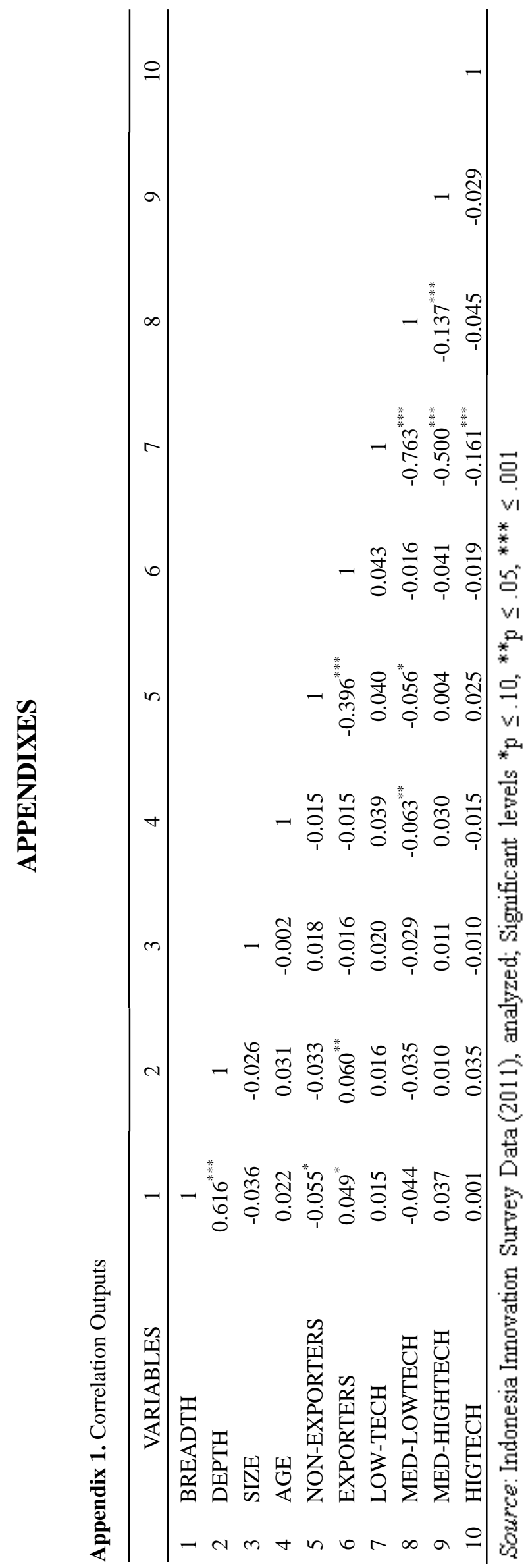

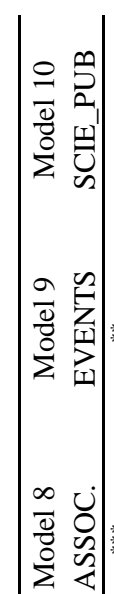

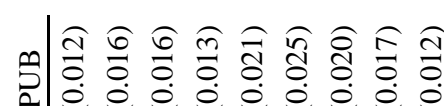

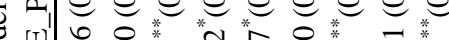
勿|

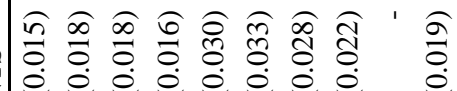

$\exists e$ e e e e e e

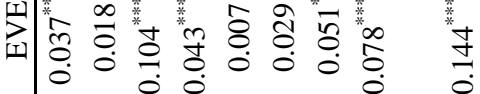

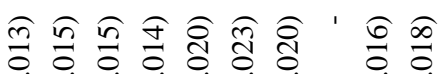

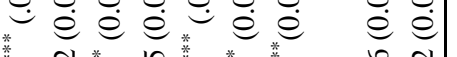

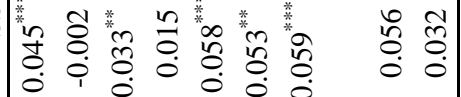

의즈는

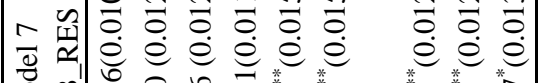

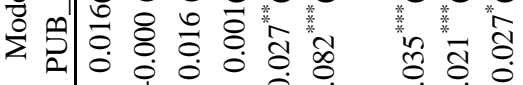

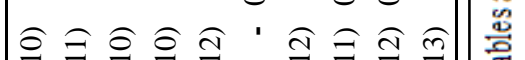

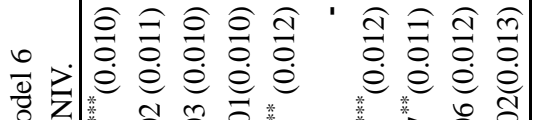

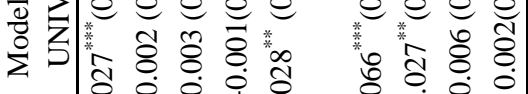

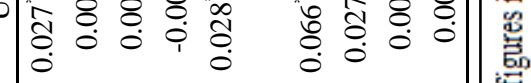

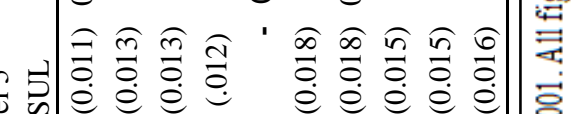

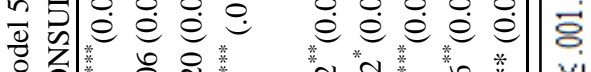

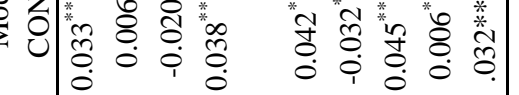

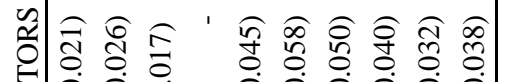

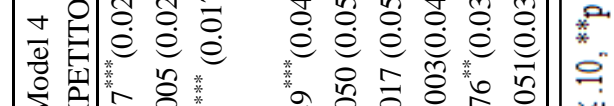

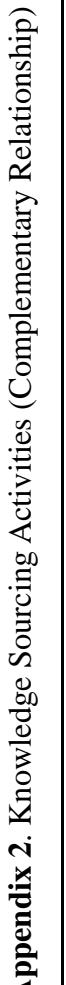

$\sum$ 渟

ㄱำ

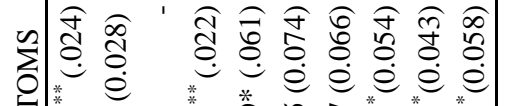

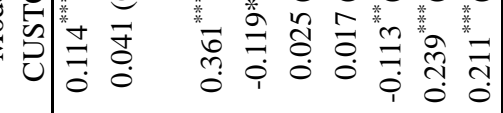

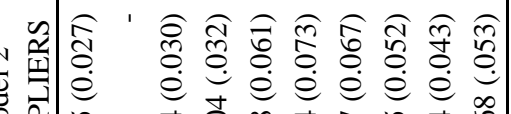

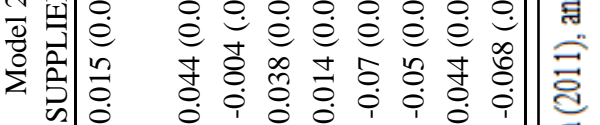

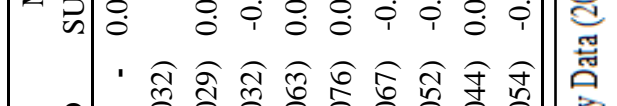

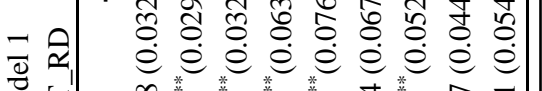

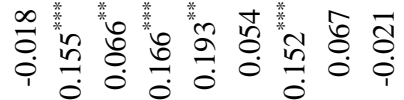

$\stackrel{\square}{\Sigma} \bar{Z}$

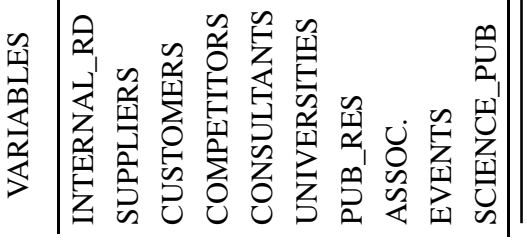

